\title{
THE ROLES OF PARTICIPANTS IN A STORYTELLING EVENT
}

\author{
Barbara Ivančič Kutin
}

\begin{abstract}
In the paper the roles adopted during the storytelling event by individual participants are discussed. During field research carried out in the Bovec area in the northwest part of Slovenia, whole storytelling meetings, at which a number of folklore events (complete stories) occurred, were audio-recorded. Phonetic transcriptions of these meetings were made from the recorded material, including next to the stories also the participants' conversations in-between the stories. On the basis of the functions of active interventions in the storytelling process, it is possible to categorise recipients under six roles: motivator, assistant, inquirer, yea-sayer/nay-sayer, complementor and commentator. A higher diversity of roles of the participants is obvious in groups of three or more participants, particularly if there is at least one recipient who knows the storyteller's repertoire.
\end{abstract}

Key words: audience, context, folklore, folk narrative, narratology, oral text, oral tradition, recipient, storytelling event, storytelling, storyteller

A folklore event is a social situation in which narration occurs. It is composed of three levels: text (wording of narration), texture (the way in which the narration is performed) and context (the circumstances in which a narration occurs) (Dundes 1980: 29-32). Every folkloric storytelling event is unique and singular, because it develops in an unrepeatable context of time, place, space, and participants. Storytelling requires, in addition to the narrator, the presence of at least one participant at whom the story is aimed - a recipient (Stanonik 2001: 228, 229). How the story develops is influenced by motivation, personal characteristics, the mood and behaviour of all the participants, and the relations between them are also very important because they determine how relaxed and effective the event is (about social and psychological context of the narrating narration see Jason 1997: 223, 224).

The effectiveness of folkloric storytelling largely depends on the storyteller: his of her narrative power with and without words determines how s/he will succeed in catching the attention of his audience and what responses s/he will draw from it. This aim requires the narrator's psychological, mental and physical engagement, resulting in creativity and authority (Ivančič Kutin 2005: 181). 
The role of storyteller may be limited to a single person, especially when there are a few participants and particularly if the only recipient is a researcher. If there are more participants - that is, at least three -, several participants can alternate in the role of the storyteller (Ivančič Kutin 2005: 182).

The participants who act as recipients respond to the story by listening, watching, commenting, asking questions, calling and producing emotional reactions.

The material documented in our field research shows that the role of recipient can be divided more accurately on the basis of forms/functions of active intervention in the course of narration: (1) motivator, (2) assistant, (3) inquirer, (4) yea-sayer or nay-sayer (censor), (5) complementor, (6) commentator. Individual recipients may engage in several of these roles and they all influence the way how the storyteller tells his or her story (Ivančič Kutin 2005: 182192).

\section{MOTIVATOR}

There are two kinds of motivators: Motivator type A is not familiar with the storyteller's repertoire and he tries to stimulate the informant's associations (e.g., Do you know some story about a death experience/a ghost/dwarfs...?). The researcher usually belongs to the first group because of his professional interest in collecting folk stories: by asking questions or providing model stories, he tries to stimulate in the storyteller associations with a certain theme to start the process of storytelling. The researcher usually adopts the role of motivator when he has an individual meeting with a storyteller whose repertoire he does not know or does not know well. Motivator type B knows the storyteller's repertoire. This group consists of people who direct the storyteller with specific incentives (e.g., Do you remember when...?; Tell us that story about ...; So, what was it like in...?).

\section{ASSISTANT}

The assistant acts as the storyteller's right hand at key moments in the story, helping him or her to recall details: a name, place, date, person, exact quote, etc. (e. g., Storyteller: ... it was ... I don't remember...; at that moment the assistant jumps in: In 1920!). In addition to supplying specific data, he may also assist in illustrating the story with gestures, facial or vocal expressions, etc. 
This role can be carried out only by someone who knows the story. The role of assistant was observed in meetings with several participants.

\section{INQUIRER}

The inquirer's typical role is to intervene in the story with questions or to ask for an explanation whenever he feels that the storyteller is not clear or illustrative enough (e.g., Who told you that story? Was it dark when it happened? Anybody else saw that?). At times the intervention shows that the inquirer did not pay enough attention, because he has heard the part of the story that is the answer to his question. The researcher often finds himself in the role of inquirer, because he is interested in other circumstances of the story that is told: he will ask, for instance, where, when and from who has the storyteller learned about the story or about other details. Sometimes the roles of motivator and inquirer are quite similar: both ask questions, but there is an essential difference: the motivator, who already knows the story, asks his questions to lead the story in a certain direction, even though he already knows the answers; the inquirer, on the other hand, seeks additional clarification.

\section{YEA-SAYER/NAY-SAYER (CENSOR)}

This role is taken up by participants who already know the story (and how it runs) either because they have already heard it or because they witnessed the event the story is about. Their comments on the story's veracity (e.g., Yeah, that's true. I remember it.) or other reactions (nodding/shaking one's head) confirm that the story is true. They intervene also when they feel that the storyteller is not giving a reliable, exact account of the event or has altered it to his own liking. At these points they intervene, usually making only minor corrections, for instance, involving a name, place or date, etc. (It was in 1900 not in 1910. I believe his name was Ivan not Janez.)

\section{COMPLEMENTOR}

Only someone who knows the content of a story can take up the role of complementor. He will complement the storyteller at points where he feels that the latter is not telling it accurately enough, so he is intervening with remarks 
about additional facts (e.g., Storyteller: It happened in winter... then complementor supplements: There was more than one meter of snow...).

\section{COMMENTATOR}

All participants may take up the role of commentator, whether they know the story or not. Some recipients comment while the story is told, but comments are more often made after a unit of the folklore event is finished. Then the storyteller comments, too. Comments include statements on the story's likelihood and emotions and other remarks inspired by the story or the way it was told (e.g., I'd do the same if I were there. This is a funny story. I don't believe it.). Comments also include all kinds of non-verbal reactions by the recipients: laughter, shouting, whistling.

During field research carried out in 1999-2004 in the Bovec area in the northwest part of Slovenia, whole storytelling meetings, at which a number of folklore events (complete stories) occurred, were audio-recorded (in particular, 15-48 units - i.e., complete stories during a single visit of informants). The number of participants in the selected storytelling meetings was two to seven. These meetings were transcribed from the records phonetically, including, beside the stories, the participants' conversations in-between the stories (Fig. $1)^{1}$.
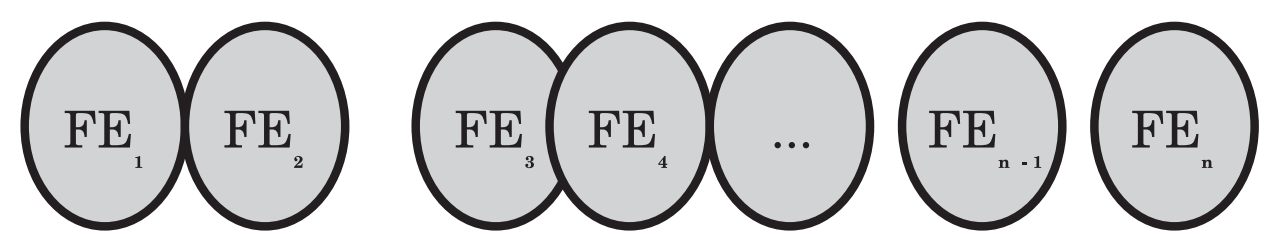

Figure 1. A storytelling meeting is a sequence of $\mathrm{n}$ number of folklore events (stories) during one field visit.

As an example, Table 1 presents the distribution of roles among the participants in a storytelling meeting with seven participants. The table lists the participants and the roles they adopted. The storyteller's cells include how many stories he or she told. 
Table 1. Roles of participants in the storytelling meeting in Bovec on November $1,2000$.

\begin{tabular}{|l|c|c|c|c|c|c|c|}
\hline \multirow{2}{*}{ Roles } & \multicolumn{7}{|c|}{ Participant } \\
\cline { 2 - 8 } & Zvonko & Matilda & Alenka & $\begin{array}{l}\text { Barbara } \\
\text { (re- } \\
\text { searcher) }\end{array}$ & Ivanka & Damijan & Aldo \\
\hline $\begin{array}{l}\text { storyteller } \\
\text { No. of } \\
\text { stories) }\end{array}$ & $+(11)$ & $+(1)$ & & & $+(1)$ & & $+(8)$ \\
\hline motivator & + & + & + & & + & + \\
\hline assistant & + & + & + & + & & & + \\
\hline $\begin{array}{l}\text { inquirer } \\
\text { yea-/nay- } \\
\text { sayer }\end{array}$ & + & + & & & & & + \\
\hline $\begin{array}{l}\text { comple- } \\
\text { mentor }\end{array}$ & & + & & & + & + & + \\
\hline $\begin{array}{l}\text { commen- } \\
\text { tator }\end{array}$ & + & + & + & + & + & + & + \\
\hline
\end{tabular}

One of the 21 stories told at this storytelling meeting was chosen as an example. The original Slovene version was phonetically transcribed from the audio tape: in dialect and literally as it was told; non-verbal interventions and remarks on how they were made are shown in italics.

The example story was translated in a type of spoken English. ${ }^{2}$ This means that some characteristics of colloquial language, such as repetitions, non-literary words, and grammatical forms, was tried to be kept.

Four to seven participants participated actively in this specific unit. Four different roles, beside the storyteller, were discerned: motivator (type B), inquirer, complementor and commentator. The transcription shows that the storyteller (Zvonko) also acted as inquirer (at the beginning) and commentator (at the end of the unit).

WHO'S TOO BOLD, GETS WHAT'S COMING TO HIM

Alenka as motivator type B: Tell us about the guy who drove nails into a coffin. 
Zvonko: Yeah, that's one my uncle used to tell.

Barbara as inquirer: Which uncle?

Zvonko: Lou, the one who lived here. Remember him?

Barbara: Yes, yes.

Zvonko: Well, he's the one who told it. They made a bet, you know. They made a bet, yes, they bet on five or ten litres of wine. They said: "Go up to the cemetery if you dare. There's a coffin up there ..."

You know, up in the cemetery they had these wooden coffins outside, by the chapel, if they needed one. "Well, up there's a coffin and you have to drive nails in it." Take a hammer and nails with you and drive the nails in the coffin. And make sure you really drive them in, 'cause we'll go and check these in the morning. "OK, I'll do it (resolute)," he said, "I'll do it, I'll take a hammer and three nails and off I go. You think I'm scared!? No way (confident)!!! Coffin, here I come!"

Well, and then this guy goes up the cemetery and he starts driving those nails, the three nails in the coffin. And as he leans on the coffin (stands up and stretches out his jacket over the table to show)...

Aldo as inquirer (in-between): His jacket gets caught?

Zvonko: ....and he drives a nail through his jacket, 'cause it's dark and he don't see a thing. No, he don't see a thing when he leans on that old coffin and drives the nail right (shows) through his jacket, see? And after he's driven in the three nails, he wants to go...

Aldo as complementor (jumps in): But he's caught!

Zvonko: ... Yeah, he's caught, because he's driven it right through, you see. Oh horror!!! And in the morning they find him dead up there!

Aldo as commentator: Of fear.

Barbara as commentator: Had a stroke.

Zvonko as commentator: Yeah, had a stroke out of fear. Well, that's what my uncle told.

\section{CONCLUSION}

A higher diversity of roles of the participants is obvious in groups of three or more participants. Such a group acts in cooperation, especially if one of them is very apt to motivate. The roles of motivator type B, assistant, yea-sayer/ nay-sayer and complementor prove that the narration (story) is a re-enactment of a version of the story the recipients are familiar with. This means that the story was already told and heard, so it is still alive in oral tradition. 


\section{COMMENTS}

${ }^{1}$ It is very important to observe the conversation between one and the next folklore event (see empty space), which does not belong to the preceding or the following story, if we want to find out the roles of the participant. The figure shows that sometimes the end of one story is the beginning of the next one at the same time.

2 Translated by Franc Smrke.

\section{REFERENCES}

Dundes, Alan 1980. Texture, Text, and Context. Interpreting Folklore. Bloomington (Indiana): Indiana University Press, pp. 20-32.

Jason, Heda 1997. Texture, Text and Context of the Folklore Text vs. Indexing. Journal of Folklore Research, Vol. 34, (3)(September-December), pp. 221-225.

Ivančič Kutin, Barbara 2003. Raziskovalni položaji pri terenskem zbiranju prozne folklore. [Research methods of collecting oral literature in the field.] Traditiones, 32: 1. Ljubljana: Slovenska akademija znanosti in umetnosti, pp. 117-124.

Ivančič Kutin, Barbara 2005. Kontekst in tekstura folklornih pripovedi na Bovškem (Context and texture of folklore narratives in the Bovec area). PHD thesis. Ljubljana: Faculty of Arts, University of Ljubljana.

Stanonik, Marija 2001. Teoretični oris slovstvene folklore.(Theoretical features of Slovenian literary folklore). Ljubljana: Založba ZRC, ZRC SAZU. 